\title{
Effect of Sequential Application of Different Pre and Post Emergence Herbicides on Growth and Yield of Direct Seeded Rice
}

\author{
Ajay Kumar ${ }^{1 *}$, Sanjay Kumar ${ }^{1}$, Swaraj Kumar Dutta ${ }^{1}$, Shweta Shambhavi², \\ Mainak Ghosh ${ }^{1}$ and Subrat Keshori Behera ${ }^{3}$
}

${ }^{1}$ Department of Agronomy, ${ }^{2}$ Department of Soil science and Agricultural chemistry, ${ }^{3}$ Department of Statistics, Mathematics and Computer Application, Bihar Agricultural University, Sabour, Bhagalpur-813210, India

*Corresponding author

\begin{tabular}{l} 
Key w o r d s \\
$\begin{array}{l}\text { Direct seeded rice, } \\
\text { Pendimethalin, Pre- } \\
\text { emergence, Post } \\
\text { emergence }\end{array}$ \\
\hline Article Info \\
$\begin{array}{l}\text { Accepted: } \\
15 \text { August } 2020 \\
\text { Available Online: } \\
10 \text { September } 2020\end{array}$ \\
\hline
\end{tabular}

\section{A B S T R A C T}

A field experiment was conducted during kharif season of 2019-20 at Agricultural Research farm of Bihar Agricultural University, Sabour, Bhagalpur (Bihar) to study the effect of sequential application of different pre and post emergence herbicides on growth and yield of direct seeded rice. The experiment was laid out in split plot design with three replications having twenty treatment combinations consisting of four pre-emergence herbicides (main plot) and five post-emergence herbicides (sub plot). Application of Pendimethalin @ $1000 \mathrm{~g}$ a.i. ha ${ }^{-1}$ as pre-emergence $f b$ Bispyribac@25 g a.i. ha ${ }^{-1}+$ Pyrazosulfuron@20 g a.i. ha ${ }^{-1}$ as postemergence recorded significantly highest grain yield $\left(4.63 \mathrm{t} \mathrm{ha}^{-1}\right)$, effective tillers $\mathrm{m}^{-2}$ (361), LAI and no. of tillers $\mathrm{m}^{-2}$. From this study, it may be concluded that the application of Pendimethalin @ $1000 \mathrm{~g}$ a.i. ha ${ }^{-1}$ (PE) $f b$ Bispyribac@25 g a.i. ha ${ }^{-1}+$ Pyrazosulfuron@20 ga. i. ha ${ }^{-1}$ (PoE) may be a viable option for weed control in direct seeded rice with improvements in plant growth, yield attributes and yield.

\section{Introduction}

Rice is the staple food crop for over $60 \%$ of the world population. India ranks $2^{\text {nd }}$ position in the production of rice in the world. Rice provides $30-75 \%$ of the total calories to more than 3 billion Asians (Khush, 2004). On the basis of population projections from the United Nations and income projections, the Food and Agricultural Policy Research Institute (FAPRI) has assumed that global rice demand is expected to rise 555 million tons in 2035 which will be a challenging task for all agriculturists. At present labour crisis and 
depleting water resources are arising as major problems in agriculture. In this scenario, direct seeded rice (DSR) is now emerging as an alternative production system to traditional puddle transplanted rice (PTR) in India (Mahajan et al., 2012) especially in the northwest Indo Gangetic Plains. DSR systems face high weed infestation than the PTR system. DSR systems lacking 'head start' due to direct sowing, lack of flooding and alternate wetting and drying resulting it becomes more vulnerable to weed competition during the initial stage of the crop growth (Rao et al., 2007). In DSR, weeds emerge at the same time with crop seedlings and the initial weed growth is rapid in moist soil as that in puddled transplanted rice causing severe competition for resources to the crop (Khaliq and Matloob, 2011). The critical period of cropweed competition in direct seeded rice varies from 20-50 DAS (Khaliq and Matloob, 2011). In this way, timely weed control is pivotal to maximize rice profitability. According to Chauhan and Opeña (2012), weeds are major biological hurdle to growing of direct seeded rice and inability to weeds control results 50 to $90 \%$ yield losses. Manual weeding or handweeding by hoe are conventional techniques of weed control in rice, but today this is less convenient and less advantageous due to labour shortage at the crucial time of weeding (Kumar and Ladha, 2011). Besides, some grassy weeds, for example, Echinochloa crusgalli L. appears to be like rice seedlings at the early stage of growth, making hand weeding more tedious, difficult, and less effective. In this circumstances, utilization of herbicides is getting more popularity in direct seeded rice cultivation due to their greater effectiveness, easier application, selectivity to the crop, saving labour and economic in use too (Singh et al., 2016).

Chemical weed control in DSR has risen as a promising solution to the weed problem. However, the application of pre-emergence herbicide alone may not control the wide range of weed population and several flushes of weeds that emerge at different developmental phases of rice crop. Hence, the use of sequential application of preemergence herbicides followed by $(f b)$ application of post-emergence herbicides or pre-emergence herbicides $f b$ manual weeding could be more convenient in reducing the weed pressure in DSR (Yogananda et al., 2019). Patel et al., (2018) observed significant improvement in growth, yield attributes and yield of direct seeded rice by applying Pretilachlor @ $1250 \mathrm{~g} / \mathrm{ha}$ as pre-emergence $f b$ Bispyribac-sodium salt @ $50 \mathrm{~g} / \mathrm{ha}$ at 30 DAS as post-emergence. Yadav et al., (2014) stated that application of Pendimethalin $1 \mathrm{~kg} / \mathrm{ha}$ (PE) $f b$ Azimsulfuron $17.5 \mathrm{~g} / \mathrm{ha}+$ Bispyribac $25 \mathrm{~g} / \mathrm{ha}$ (PoE) $f b 1$ hand weeding recorded highest plant height, grain yield and yield attributing characters such as number of panicles $/ \mathrm{m}^{2}$, number of grains/panicle, test weight. There is lacking of research on the suitable herbicidal combination for direct seeded rice, particularly in the Indian context. Hence the present study was undertaken to assess the efficacy of different herbicides on growth, yield and yield attributes of direct seeded rice.

\section{Materials and Methods}

\section{Experimental site}

A field experiment was carried out during kharif season of 2019-20 at CropResearch Farm of Bihar Agricultural University, Sabour, Bhagalpur, Bihar, India. Bhagalpur falls under Middle Gangetic Plain Region and Agro-Climatic Zone III-A of Bihar state. It is situated between $25^{\circ} 15^{\prime} 40 \mathrm{~N}$ latitude and $87^{\circ} 2^{\prime} 45^{\prime \prime}$ E longitude with an altitude of 37.19 meters above the mean sea level (AMSL).

The soil of the experimental site was loamy sand having $\mathrm{pH}$ 7.6, electrical conductivity $0.31 \mathrm{dS} \mathrm{m}^{-1}$, organic carbon $0.51 \%$, bulk 
density $1.34 \mathrm{Mg} \mathrm{m}^{-3}$, available $\mathrm{N} 209.2 \mathrm{~kg} \mathrm{ha}$ 1 , available $\mathrm{P}_{2} \mathrm{O}_{5} 38.5 \mathrm{~kg} \mathrm{ha}^{-1}$ and available $\mathrm{K}_{2} \mathrm{O} 151.4 \mathrm{~kg} \mathrm{ha}^{-1}$.

\section{Climatic and weather conditions of the research site}

The climate of the experimental area is subtropical characterized by hot dry summer, cold winter and moderate annual precipitation. May is the hottest month records average maximum temperature of 35 to $39^{\circ} \mathrm{C}$. January is the coldest month records average minimum temperature within 5 to $10^{\circ} \mathrm{C}$. The average annual rainfall of the experimental site is $1167.0 \mathrm{~mm}$, and about 75 to $80 \%$ of which precipitates from 15 June to 15 October and there is very scanty rainfall during the remaining period. Daily meteorological observations during the crop growth period have been shown in Fig. 1.

\section{Experimental details}

The experiment was conducted in split-plot design with three replication containing twenty treatments combinations of four preemergence herbicides viz. No Pre-emergence $\left(\mathrm{PE}_{1}\right)$, Pendimethalin $\left(\mathrm{PE}_{2}\right) @ 1000 \mathrm{~g}$ a.i. $\mathrm{ha}^{-1}$, Oxadiargyl ( $\left.\mathrm{PE}_{3}\right) @ 500 \mathrm{~g}$ a.i. $\mathrm{ha}^{-1}$ and Pretilachlor $\left(\mathrm{PE}_{4}\right) @ 500 \mathrm{~g}$ a.i. ha ${ }^{-1}$ as main plots, and five post-emergence herbicides: $\mathrm{PoE}_{1}$ :No Post-emergence, PoE 2 : Bispyribac @(25 g a.i. ha ${ }^{-1}, \mathrm{PoE}_{3}$ : Bispyribac @ $25 \mathrm{~g}$ a.i. ha $^{-1}+$ Pyrazosulfuron @ 20 g a.i. ha ${ }^{-1}, \mathrm{PoE}_{4}$ : Fenoxoprop@ 56 g a.i. ha ${ }^{-1}+$ Ethoxysulfuron @ $18 \mathrm{~g}$ a.i. ha ${ }^{-1}, \mathrm{PoE}_{5}$ : Fenoxoprop @ $56 \mathrm{~g}$ a.i. ha ${ }^{-1} f b$ Halosulfuron@67 g a.i. ha ${ }^{-1}$ as sub plot treatment.

Pre-emergence herbicides and post emergence herbicides were applied at 2 DAS and 25 DAS respectively. Total no. of plots were 60 and net plot size of each plot was $22.5 \mathrm{~m}^{2}$. The rice variety Rajendra Sweta was sown on 29 June 2019 with $20 \mathrm{~cm}$ (R-R) spacing and $25 \mathrm{~kg} / \mathrm{h}$ a seed rate. The recommended dose of fertilizer i.e. 120: 60: 40: $\left(\mathrm{N}: \mathrm{P}_{2} \mathrm{O}_{5}: \mathrm{K}_{2} \mathrm{O} \mathrm{Kg}\right.$ $\mathrm{ha}^{-1}$ ) was applied. The crop was harvested on 10 Nov 2019.

\section{Results and Discussion}

\section{Effect on crop growth}

Growth of the crop was assessed in the term of plant height $(\mathrm{cm})$, leaf area index (LAI) and number of tillers $\mathrm{m}^{-2}$. There was significant effect of different weed control treatments on growth parameters. Plant height increased with the age of the crop, continuously up to the time of harvest. Among pre-emergence herbicides, significantly highest plant height was recorded with Pendimethalin @ $1000 \mathrm{~g}$ a.i. $\mathrm{ha}^{-1}$ at 30 DAS and 90 DAS. But, it recorded significantly higher with Pretilachlor @ $500 \mathrm{~g}$ a.i. ha ${ }^{-1}$ at 60 DAS and at harvest stage, being at par with Pendimethalin@1000 g a.i. ha ${ }^{-1}$ and Oxadiargyl@ 500 g a.i. ha ${ }^{-1}$.In the case of post-emergence herbicides, Bispyribac@25 g a.i. ha ${ }^{-1}+$ Pyrazosulfuron@ 20 g a.i. ha ${ }^{-1}$ recorded significantly higher plant height at all the growth stages of direct seeded rice, i.e., 30, 60, 90 DAS and at harvest. No pre and no post-emergence herbicides recorded lowest plant height due to heavy weed competition (Fig. 2). In case of leaf area index (LAI), it is clear that Pendimethalin@1000 g a.i. ha ${ }^{-1}$ recorded higher LAI among the preemergence herbicides, which was at par with Pretilachlor and Oxadiargyl, at all the growth stages i.e. 30, 60 and 90 DAS. In case of postemergence herbicides Bispyribac @ $25 \mathrm{~g}$ a.i. $\mathrm{ha}^{-1}+$ Pyrazosulfuron@ $20 \mathrm{~g}$ a.i. ha ${ }^{-1}$ recorded significantly higher LAI at all the growth stages of direct seeded rice i.e., 30, 60 and 90 DAS (Fig. 3).

In case of no. of tillers $\mathrm{m}^{-2}$, it is obvious that application of Pendimethalin@ $1000 \mathrm{~g}$ a.i. ha (PE) $f b$ Bispyribac @ 25 g a.i. $h^{-1}+$ Pyrazosulfuron @20 g a.i. ha ${ }^{-1}$ (PoE) recorded significantly number of tillers $\mathrm{m}^{-2}$ 
(Fig. 4). This might be due to effective reduction of weed population by Pendimethalin at the early stage of rice growth and thereby providing congenial environment for the growth of rice. The weeds which emerged at later stages were also effectively controlled by the application of Bispyribac + Pyrazosulfuron. Results were in conformity with Wallia et al., (2012) and Yadav et al., (2018).

\section{Effect on yield attributes}

The data on yield attributing characters such as effective tillers meter ${ }^{-2}$, panicle length (cm), number of grains panicle ${ }^{-1}$ and 1000 grain weight (g) were recorded and their analysis showed significant effect due to application of different $\mathrm{PE}$ and $\mathrm{PoE}$ herbicides.

Among pre-emergence herbicides, significantly higher effective tillers meter $^{-2}$ (344), panicle length $(20.91 \mathrm{~cm})$, number of grains panicle ${ }^{-1}(110)$ and 1000 grain weight $(15.24 \mathrm{~g})$ were recorded with Pendimethalin @ $1000 \mathrm{~g}$ a.i. ha ${ }^{-1}$ which was at par with Pretilachlor@ $500 \mathrm{~g}$ a.i. ha ${ }^{-1}$. In case of postemergence herbicides, significantly higher effective tillers meter ${ }^{-2}$ (348), number of grains panicle $^{-1}(114)$ and 1000 grain weight $(15.23 \mathrm{~g})$ were recorded with the application of Bispyribac @ $25 \mathrm{~g}$ a.i. ha ${ }^{-1}+$ Pyrazosulfuron@20 g a.i. ha ${ }^{-1}$, while panicle length $(20.80 \mathrm{~cm})$ was recorded significantly higher with Bispyribac@ 25 g a.i. ha ${ }^{-1}$, which was found statistically at par with Bispyribac + Pyrazosulfuron, Fenoxoprop + Ethoxysulfuron and Fenoxoprop $f b$ Halosulfuron.

This may be due to lower weed infestation, which enabled the rice crop to remove adequate amount of nutrient and water, resulting in better growth of crop and provided better yield attributes. Results were in conformity with Wallia et al., (2012) (Table 1).

Fig.1 Daily meteorological observations during the crop growth period

(From June 2019 to Nov 2019)

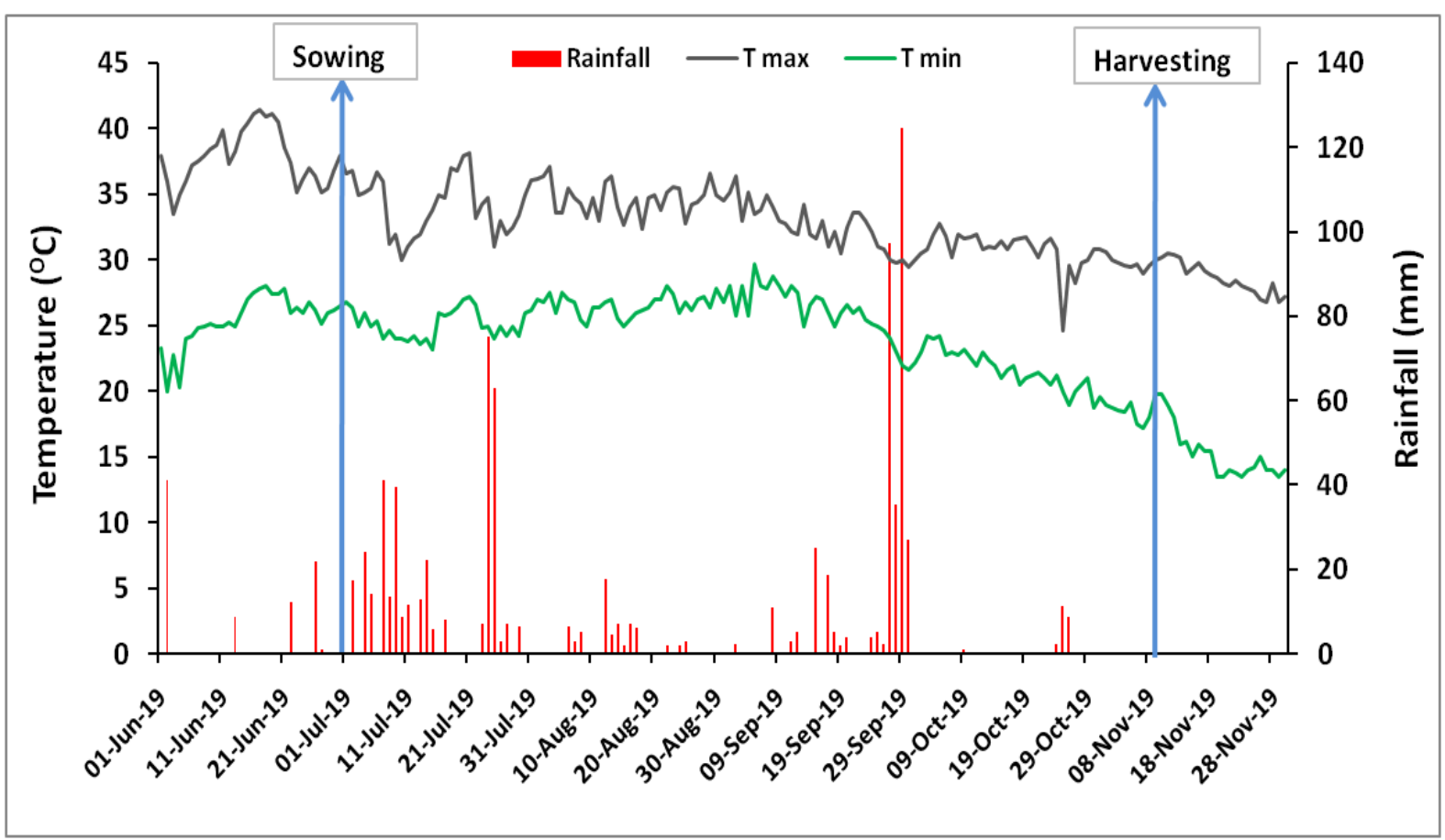


Fig.2 Effect of pre and post emergence herbicide application on plant height $(\mathrm{cm})$ of direct seeded rice

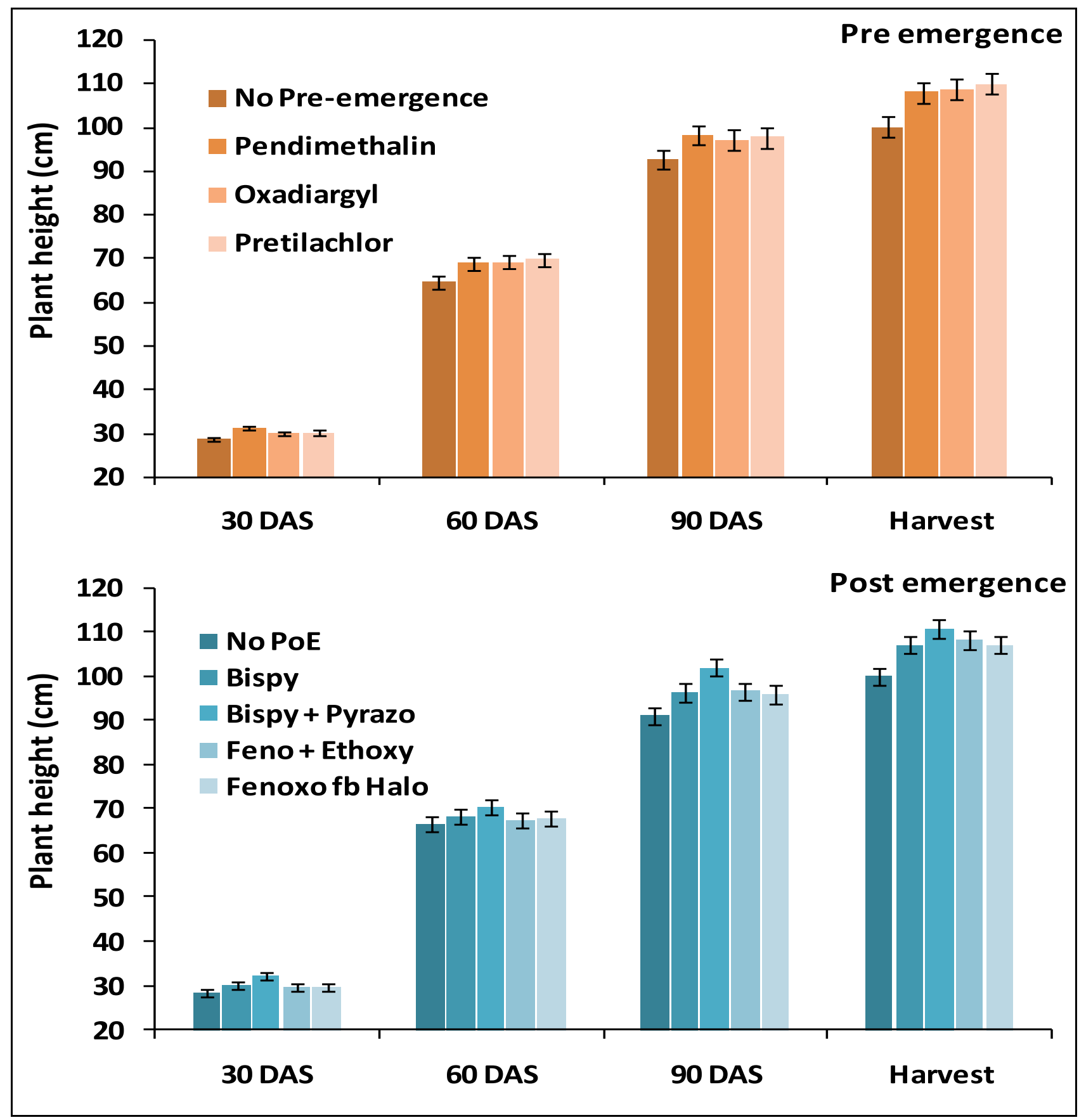

No PoE:- No post emergence; Bispy:- Bispyribac; Bispyri + Pyrazo:- Bispyribac + Pyrazosulfuron; Feno + Ethoxy :- Fenoxoprop + Ethoxysulfuron; Fenoxo fb Halo:- Fenoxoprop $f b$ Halosulfuron 
Fig.3 Effect of pre and post emergence herbicide application on LAI of direct seeded rice

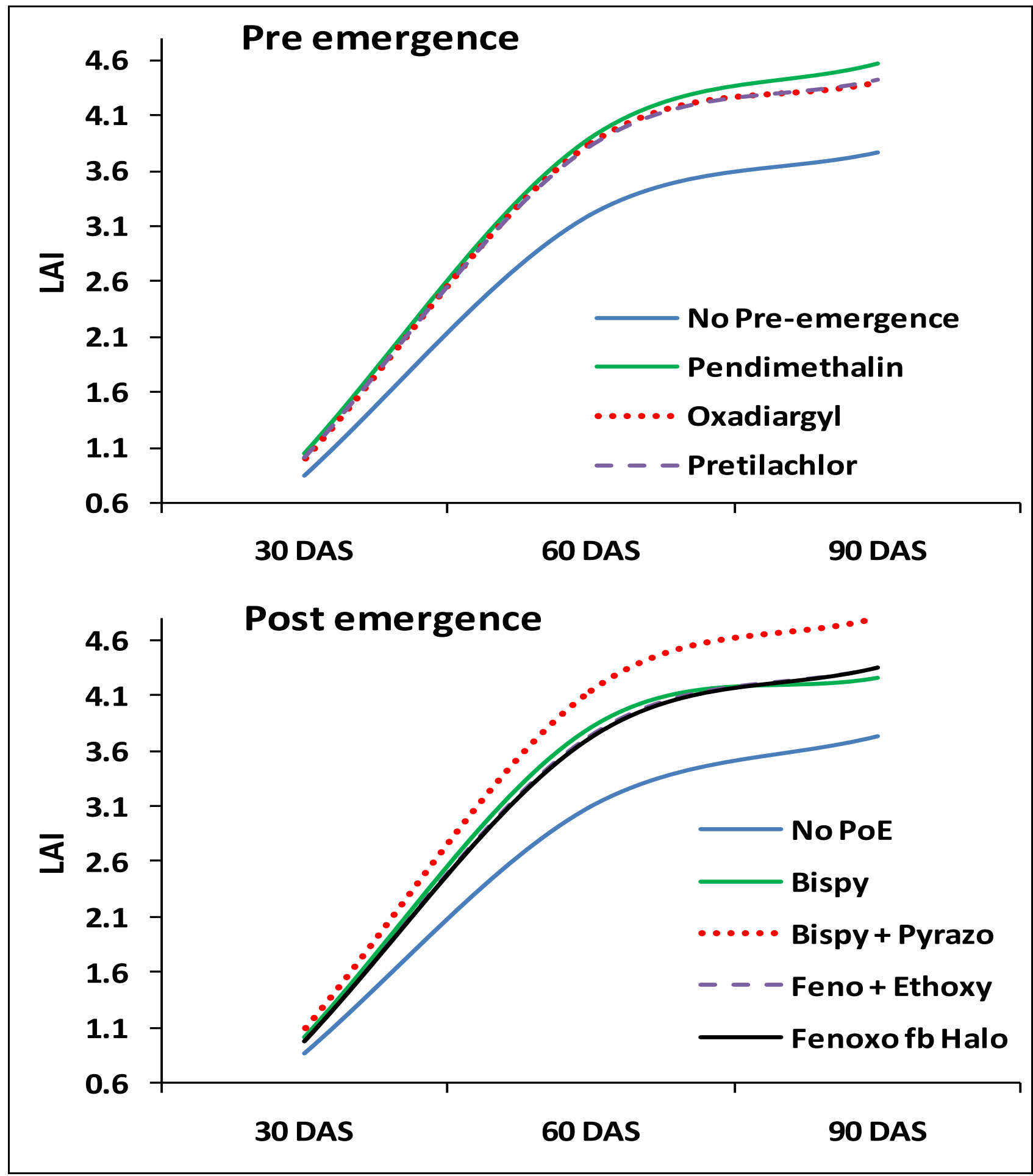

No PoE:- No post emergence; Bispy:- Bispyribac; Bispyri + Pyrazo:- Bispyribac + Pyrazosulfuron; Feno + Ethoxy :- Fenoxoprop + Ethoxysulfuron; Fenoxo fb Halo:- Fenoxoprop $f b$ Halosulfuron 
Fig.4 Effect of pre and post emergence herbicide application on tillers $/ \mathrm{m}^{2}$ of direct seeded rice

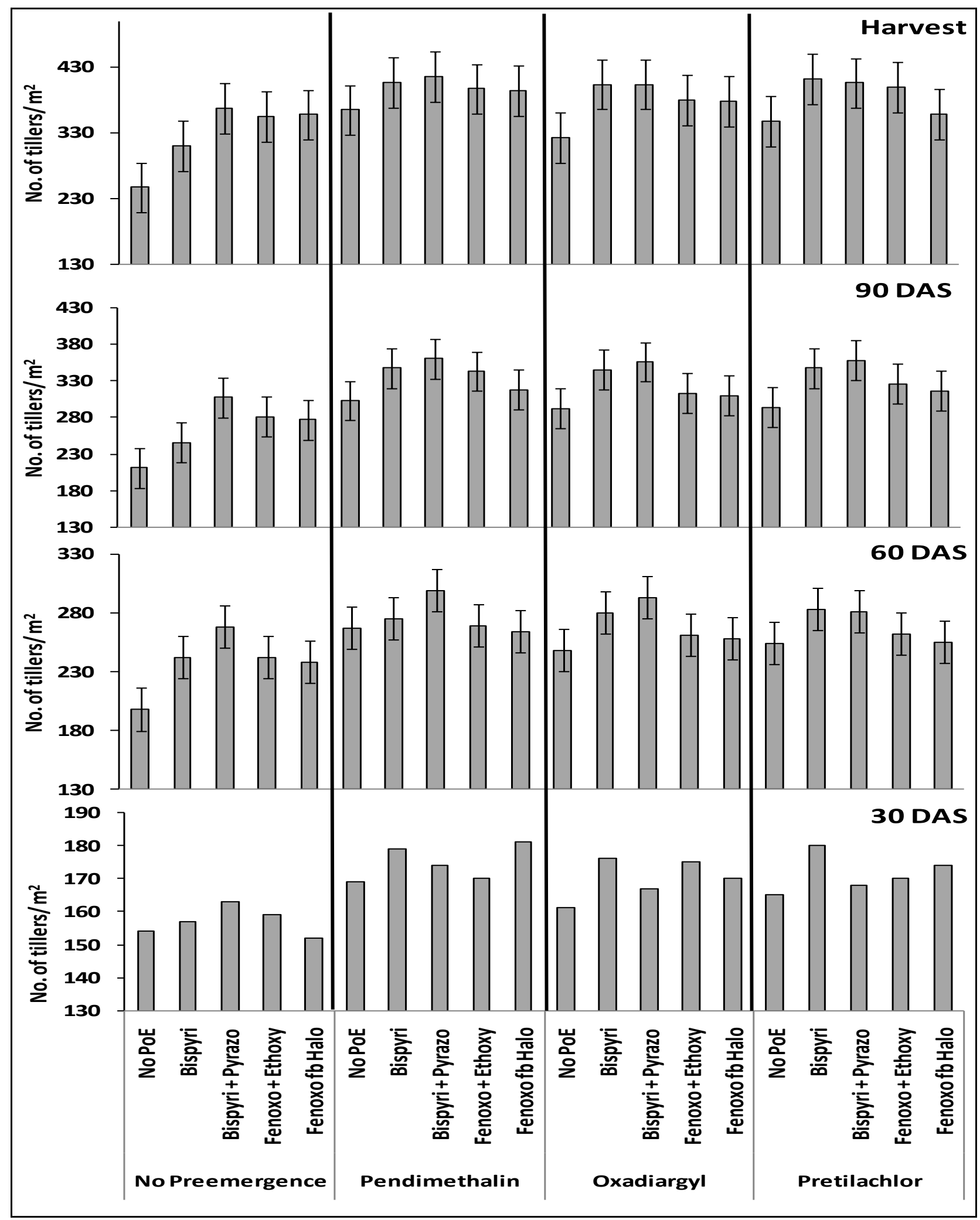

No PoE:- No post emergence; Bispyri- Bispyribac; Bispyri + Pyrazo:- Bispyribac + Pyrazosulfuron; Fenoxo + Ethoxy :- Fenoxoprop + Ethoxysulfuron; Fenoxo fb Halo:- Fenoxoprop $f b$ Halosulfuron 
Table.1 Yield attributes and yield of direct seeded rice as influenced by application of different pre and post-emergence herbicides

\begin{tabular}{|c|c|c|c|c|c|c|c|c|}
\hline Treatment & $\begin{array}{l}\text { Effective } \\
\text { tillers } \mathbf{m}^{-2}\end{array}$ & $\begin{array}{c}\text { Panicle } \\
\text { length }(\mathrm{cm})\end{array}$ & $\begin{array}{c}\text { Number of } \\
\text { grains } \\
\text { panicle }^{-1}\end{array}$ & $\begin{array}{l}1000 \text { grain } \\
\text { weight (g) }\end{array}$ & $\begin{array}{l}\text { Grain yield } \\
\text { (t/ha) }\end{array}$ & $\begin{array}{c}\text { Straw Yield } \\
\quad(\mathrm{t} / \mathbf{h a})\end{array}$ & $\begin{array}{c}\text { Total } \\
\text { biomass } \\
\text { (t/ha) }\end{array}$ & $\begin{array}{c}\text { Harvest } \\
\text { index }(\%)\end{array}$ \\
\hline \multicolumn{9}{|c|}{ Main plot (Pre emergence-herbicides) } \\
\hline No Pre-emergence & 285 & 19.73 & 103 & 15.00 & 3.08 & 5.59 & 8.67 & 35.4 \\
\hline Pendimethalin & 344 & 20.91 & 110 & 15.24 & 4.07 & 6.26 & 10.33 & 39.3 \\
\hline Oxadiargyl & 337 & 20.67 & 107 & 15.15 & 3.76 & 6.94 & 10.70 & 35.1 \\
\hline Pretilachlor & 334 & 20.89 & 108 & 15.20 & 3.89 & 6.40 & 10.29 & 38.0 \\
\hline $\mathbf{S} \operatorname{Em}( \pm)$ & 7 & 0.06 & 1 & 0.02 & 0.09 & 0.10 & 0.14 & 0.6 \\
\hline C.D at $5 \%$ & 25 & 0.22 & 3 & 0.07 & 0.31 & 0.34 & 0.48 & 2.2 \\
\hline \multicolumn{9}{|c|}{ Sub plot (Post emergence-herbicides) } \\
\hline No Post-emergence & 288 & 20.03 & 97 & 15.05 & 3.03 & 5.75 & 8.78 & 34.4 \\
\hline Bispyribac & 334 & 20.80 & 106 & 15.15 & 3.84 & 6.40 & 10.25 & 37.5 \\
\hline Bispyribac + Pyrazosulfuron & 348 & 20.77 & 114 & 15.23 & 4.21 & 6.33 & 10.54 & 40.0 \\
\hline $\begin{array}{c}\text { Fenoxoprop + } \\
\text { Ethoxysulfuron }\end{array}$ & 328 & 20.50 & 106 & 15.18 & 3.73 & 6.39 & 10.12 & 36.9 \\
\hline Fenoxoprop $f b$ Halosulfuron & 327 & 20.64 & 111 & 15.13 & 3.69 & 6.62 & 10.30 & 35.9 \\
\hline $\operatorname{S~Em~(\pm )~}$ & 5 & 0.14 & 1 & 0.02 & 0.05 & 0.18 & 0.20 & 0.6 \\
\hline C.D at $5 \%$ & 14 & 0.41 & 3 & 0.05 & 0.13 & 0.51 & 0.56 & 1.8 \\
\hline
\end{tabular}




\section{Effect on yield}

The data showed in table 1 , revealed that among main plot treatments Pendimethalin $\left(1000 \mathrm{~g}\right.$ a.i. $\left.\mathrm{ha}^{-1}\right)$ provided significantly higher grain yield (4.07 t/ha). With no preemergence herbicide application, the yield was reduced by $24 \%$. Among sub plot treatments, significantly higher grain yield was recorded with Bispyribac $\left(25 \mathrm{~g}\right.$ a.i. $\left.\mathrm{ha}^{-1}\right)$ + Pyrazosulfuron $\left(20 \mathrm{~g}\right.$ a.i. ha $\left.{ }^{-1}\right)(4.21 \mathrm{t} / \mathrm{ha})$. No post-emergence herbicide application resulted in 28\% reduction in grain yield over the best treatment. In case of interaction effect, Pendimethalin (1000 g a.i. ha $\left.{ }^{-1}\right)$ followed by Bispyibac ( $25 \mathrm{~g}$ a.i. $\left.\mathrm{ha}^{-1}\right)+$ Pyrazosulfuron $\left(20 \mathrm{~g}\right.$ a.i. $\left.\mathrm{ha}^{-1}\right)$ gave significantly highest grain yield $(4.63 \mathrm{t} / \mathrm{ha})$ which was $55 \%$ more than the treatment no pre-and post-emergence herbicide application. In case of straw yield, among pre-emergence herbicides, significantly highest straw yield (6.94 t/ha) was recorded with Oxadiargyl@ $500 \mathrm{~g}$ a.i. ha ${ }^{-1}$ whereas among post-emergence herbicides, significantly highest straw yield (6.62 t/ha) was recorded with Fenoxoprop $f b$ Halosulfuron which was found statistically at par with Bispyribac, Bispyribac + Pyrazosulfuron and Fenoxoprop + Ethoxysulfuron. In case of total biomass, among pre-emergence herbicides, significantly highest total biomass (10.70 t/ha) was recorded with Oxadiargyl@ $500 \mathrm{~g}$ a.i. ha ${ }^{-1}$, which was at par with Pendimethalin and Pretilachlor while among post-emergence herbicides, significantly highest total biomass $(10.54 \mathrm{t} / \mathrm{ha})$ was recorded with Bispyribac + Pyrazosulfuron which was at par with Bispyribac, Fenoxoprop + Ethoxysulfuron, Fenoxoprop $f b$ Halosulfuron. In case of harvest index, among pre-emergence herbicides, significantly higher harvest index $(39.3 \%)$ due to the pre-emergence application of Pendimethalin which was statistically at par with Pretilachlor, whereas among postemergence herbicides, Bispyribac +
Pyrazosulfuron recorded significantly highest harvest index $(40.0 \%)$. No pre-emergence $f b$ no post-emergence recorded the lowest harvest index. This was due to better elimination of weeds, highest weed control efficiency provided by the best treatment and the crop used the available resources effectively during the entire crop growth period and better transfer of photosynthates into the sink resulting in maximum grain yield, straw yield, total biomass and harvest index. Results are in conformity with Saphi $e t$ al., (2018) and Gaire et al., (2019).

In conclusion, considering the losses caused by weeds in direct seeded rice and based on findings of the investigation for one season data on different weed management practices, it may be concluded that the crop growth, yield and yield attributing characters of DSR was recorded maximum when the crop was subjected to minimum weed competition with the application of Pendimethalin @ $1000 \mathrm{~g}$ a.i. $\mathrm{ha}^{-1}$ as pre-emergence at 2 days after sowing followed by Bispyribac @ $25 \mathrm{~g}$ a.i. ha $^{-1}+$ Pyrazosulfuron@20 g a.i. ha ${ }^{-1}$ as postemergence application at 25 days after sowing. The combination of pre emergence and post emergence herbicide application also resulted in higher grain yield in DSR crop as compared to no pre or post emergence herbicide application. Application of suitable combination of herbicide holds considerable promise for effective weed control and enhance the yields in DSR through better crop growth and development.

\section{References}

Chauhan, BS. and Ope na, J. 2012. Effect of tillage systems and herbicides on weed emergence, weed growth, and grain yield in dry-seeded rice systems. Field Crops Research. 137, 56-69.

Gaire, A., Amgain, LP. and Gautam, DD. 2019. Chemical weed control of dry 
direct-seeded rice under zero tillage in central mid-hill region of Nepal. Indian Journal of Weed Science. 51(3): 290 294.

Khaliq, A. and Matloob, A. 2011. Weed-crop competition period in three fine rice cultivars under direct-seeded rice culture. Pakistan Journal of Weed Science Research. 17(3):229-243.

Khush, GS., 2004. Harnessing science and technology for sustainable rice-based cropping systems. FAO Rice Conference. 53, 17-23.

Kumar, V. and Ladha, JK. 2011. Direct Seeding of Rice: Recent Developments and Future Research Needs. Advances in Agronomy, International Rice Research Institute, India office, Pusa, New Delhi, India. 111, 297-413.

Mahajan, G., Chauhan, BS., Timsina, J., Singh, PP. and Singh, K. 2012. Crop performance and water and nitrogen-use efficiencies in dry-seeded rice in response to irrigation and fertilizer amounts in north west India.Field Crops Research. 134,59-70.

Patel, TU., Lodaya, DH., Italiya, AP., Patel, DD. and Patel, HH. 2018. Bio-efficacy of herbicides in direct-seeded rice. Indian Journal of Weed Science. 50(2): $120-123$.

Rao, AN., Johnson, DE., Sivaprasad, B., Ladha, JK. and Mortimer, AM. 2007. Weed management in direct-seeded rice. Advances in Agronomy. 93, 153255.

Saphi, DK., Yadav, DR., Yadav, RK. and
Yadav, R. 2018.Yield and yield attributing characters of promising rice genotypes under dry direct seeded conditions as affected by varieties and weed control methods. International Journal of Applied Sciences and Biotechnology. 6(4): 313-318.

Singh, V., Jat, ML., Ganie, ZA., Chauhan, BS. and Gupta, RK. 2016. Herbicide options for effective weed management in dry direct seeded rice under scented rice-wheat rotation of western IndoGangetic Plains. Crop Protection. 81, 168-176.

Walia, US., Walia, SS., Sidhu, AS. and Nayyar, S. 2012. Bioefficacy of pre and post-emergence herbicides in directseeded rice in Central Punjab. Indian Journal of Weed Science. 44(1):30-33.

Yadav, RI., Singh, MK. and Singh, RK. 2014. Integrated weed management and crop establishment method for higher yield in direct-seeded rice. Indian Journal of Weed Science. 46(2): 166-168.

Yadav, RI., Singh, MK., Singh, RK. and Nagargade, M. 2018. Planting methods and weed management to improve yield in dry-seeded rice. Indian Journal of Weed Science. 50(1):22-26.

Yogananda, SB., Thimmegowda, P. and Shruthi, GK. 2019. Sequential application of pre- and post-emergence herbicides for control of complex weed flora in dry direct-seeded rice under Cauvery command area of Karnataka. Indian Journal of Weed Science. 51(2): $111-115$.

\section{How to cite this article:}

Ajay Kumar, Sanjay Kumar, Swaraj Kumar Dutta, Shweta Shambhavi, Mainak Ghosh and Subrat Keshori Behera. 2020. Effect of Sequential Application of Different Pre and Post Emergence Herbicides on Growth and Yield of Direct Seeded Rice. Int.J.Curr.Microbiol.App.Sci. 9(09): 2005-2014. doi: https://doi.org/10.20546/ijcmas.2020.909.250 